SRNL-STI-2012-00578

Revision 0

Keywords: Compressive

Strength, Cement, Flow

Retention: Permanent

\title{
Relationship Between Flowability and Tank Closure Grout Quality
}

\author{
C. A. Langton \\ D. B. Stefanko \\ M. S. Hay
}

October 2012

Savannah River National Laboratory

Savannah River Nuclear Solutions, LLC Aiken, SC 29808

Prepared for the U.S. Department of Energy under contract number DE-AC09-08SR22470.

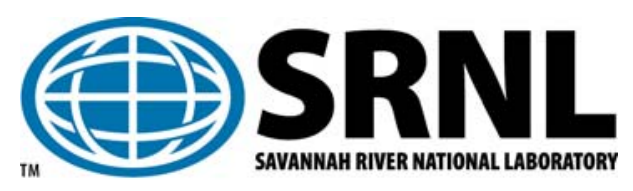


SRNL-STI-2012-00578

Revision 0

\section{DISCLAIMER}

This work was prepared under an agreement with and funded by the U.S. Government. Neither the U.S. Government or its employees, nor any of its contractors, subcontractors or their employees, makes any express or implied:

1. warranty or assumes any legal liability for the accuracy, completeness, or for the use or results of such use of any information, product, or process disclosed; or

2. representation that such use or results of such use would not infringe privately owned rights; or

3. endorsement or recommendation of any specifically identified commercial product, process, or service.

Any views and opinions of authors expressed in this work do not necessarily state or reflect those of the United States Government, or its contractors, or subcontractors.

\section{Printed in the United States of America}

Prepared for

U.S. Department of Energy 
SRNL-STI-2012-00578

Revision 0

\section{REVIEWS AND APPROVALS}

\section{AUTHORS:}

C. A. Langton, SRNL/EPD

D. B. Stefanko, SRNL/ACP

M. S. Hay, SRNL/ACP

TECHNICAL REVIEW:

M. R. Poirier, SRNL/ACP

APPROVAL:

F. M. Pennebaker, Manager, SRNL/ACP

S. L. Marra, Manager, SRNL/E\&CPT Research Programs

P. E. Carroll, SRR/Tank Farm \& Closure Engineering 
SRNL-STI-2012-00578

Revision 0

\section{EXECUTIVE SUMMARY}

After completion of waste removal and chemical cleaning operations, Tanks 5-F and 6-F await final closure. The project will proceed with completing operational closure by stabilizing the tanks with grout. Savannah River Remediation's (SRR) experience with grouting Tanks 18-F and 19-F showed that slump-flow values were correlated with flow/spread inside these tanks. Less mounding was observed when using grouts with higher slump-flow. Therefore, SRNL was requested to evaluate the relationship between flowability and cured properties to determine whether the slump-flow maximum spread of Mix LP\#8-16 could be increased from 28 inches to 30 inches without impacting the grout quality. A request was also made to evaluate increasing the drop height from 5 feet to 10 feet with the objective of enhancing the flow inside the tank by imparting more kinetic energy to the placement.

Based on a review of the grout property data for Mix LP\#8-16 collected from Tank 18-F and 19-F quality control samples, the upper limit for slump-flow measured per ASTM C 1611 can be increased from 28 to 30 inches without affecting grout quality. However, testing should be performed prior to increasing the drop height from 5 to 10 feet or observations should be made during initial filling operations to determine whether segregation occurs as a function of drop heights between 5 and 10 feet. Segregation will negatively impact grout quality.

Additionally, increasing the delivery rate of grout into Tanks 5-F and 6-F by using a higher capacity concrete/grout pump will result in better grout spread/flow inside the tanks. 


\section{TABLE OF CONTENTS}

LIST OF TABLES


SRNL-STI-2012-00578

Revision 0

\section{LIST OF TABLES}

Table 2-1. Q Quality Control Data for Fill Material from Tanks 18-F and 19-F............. 12

\section{LIST OF FIGURES}

Figure 2-1 Relationship between compressive strength and ASTM C 1611 slump flow for sample LP\#8-16 (average of 2 cylinders) collected for quality control during Tank 18-F and 19-F closure ...................................................... 9

Figure 2-2 Relationship between averaged compressive strength results as a function of ASTM C 1611 slump flow results and projections to a 30 inch flow......... 10 
SRNL-STI-2012-00578

Revision 0

\section{LIST OF ABBREVIATIONS}

$\begin{array}{ll}\text { DOE } & \text { Department of Energy } \\ \text { FTF } & \text { F-Tank Farm } \\ \text { PA } & \text { Performance Assessment } \\ \text { QC } & \text { Quality Control } \\ \text { SRNL } & \text { Savannah River National Laboratory } \\ \text { SRR } & \text { Savannah River Remediation } \\ \text { TTR } & \text { Technical Task Request }\end{array}$


SRNL-STI-2012-00578

Revision 0

\subsection{Introduction}

Formulation LP\#8-16 was recently used as the bulk fill grout in Tanks 18-F and 19-F. ${ }^{1}$ Requirements for this mix were developed by the Savannah River National Laboratory (SRNL). ${ }^{2}$ Laboratory tests and scale-up testing was performed to confirm the suitability of this grout for filling Tanks $18-\mathrm{F}$ and $19-\mathrm{F}$ as part of the tank closure process.,

Savannah River Remediation's (SRR) experience with grouting Tanks 18-F and 19-F showed that slump-flow values were correlated with flow/spread inside these tanks and that less mounding was achieved when using grouts with higher slump-flow. Therefore, a Technical Task Request (TTR) was generated requesting SRNL to evaluate the relationship between flowability and cured properties to determine whether the slumpflow maximum spread of Mix LP\#8-16 could be increased from 28 inches to 30 inches without impacting the grout quality. ${ }^{5} \mathrm{~A}$ request was also made to evaluate increasing the drop height from 5 feet to 10 feet with the objective of enhancing the flow inside the tank by imparting more kinetic energy to the placement. 
SRNL-STI-2012-00578

Revision 0

\subsection{Discussion}

\subsection{Increase in Mix LP\#8-16 Slump Flow Specification}

Based on a review of the grout property data from the quality control sample test reports for Mix LP\#8-16 collected from Tank 18-F and 19-F quality control samples, the upper limit for slump-flow measured per ASTM C 1611 can be increased from 28 to 30 inches. As shown in Figures 2-1 and 2-2, compressive strength is not a function of slump-flow over the range of values tested. Figure 2-1 shows the relationship between the averages of two samples for each batch of grout sampled for quality control. Figure 2-2 shows the relationship between the averages of all compressive strength values as a function of slump flow. This relationship is expected to be maintained as long as the grout does not segregate (i.e., show liquid-solid separation on the spread board used in the ASTM C 1611 test). Table 2-1 contains the data used in the graphs. The data was obtained from quality control sample test reports supplied by SRR from samples taken during the recent Tank 18-F and 19-F back fill operations.

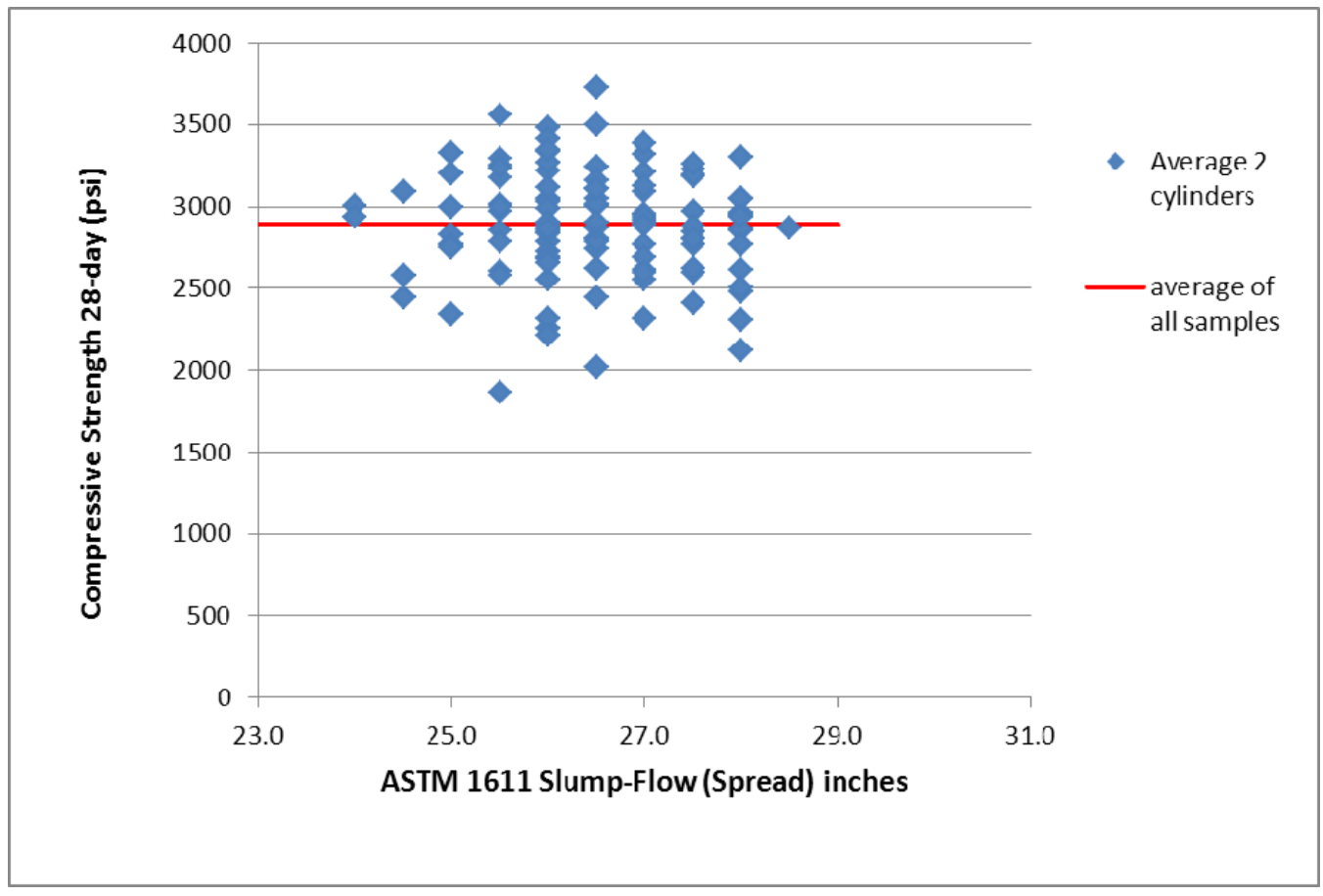

Figure 2-1 Relationship between compressive strength and ASTM C 1611 slump flow for sample LP\#8-16 (average of 2 cylinders) collected for quality control during Tank 18-F and 19-F closure. 
SRNL-STI-2012-00578

Revision 0

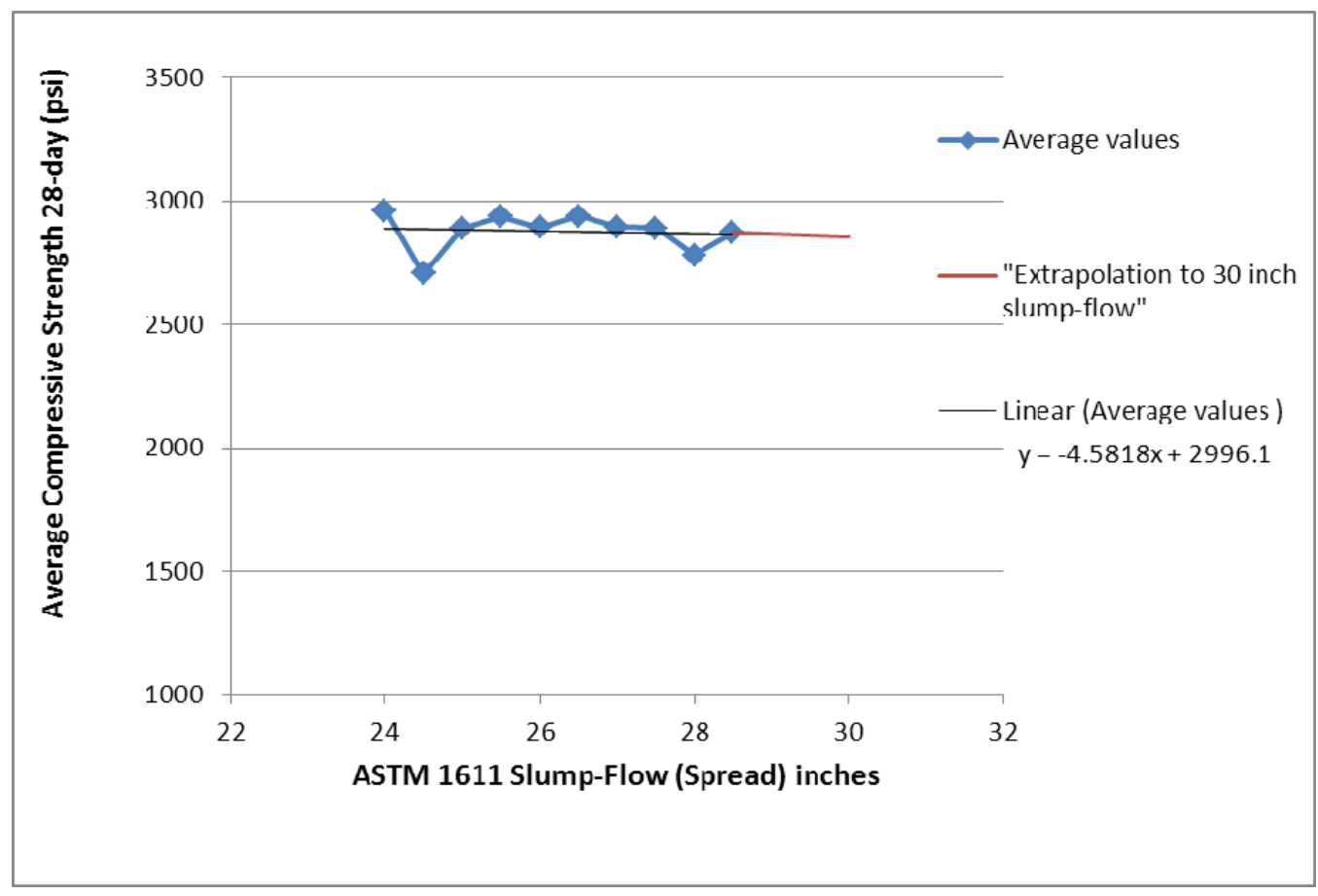

Figure 2-2 Relationship between averaged compressive strength results as a function of ASTM C 1611 slump flow results and projections to a 30 inch flow.

In addition, all of the grout placed in Tanks 18-F and 19-F had the same amount of cementitious material per unit volume and a water to cementitious material ratio of $0.57 \pm$ 0.01 (Note: one gallon of trim water was held back in most cases.). Both of these measures are reliable indicators of grout strength and other cured properties provided that placement and curing conditions are consistent.

\subsection{Increase in Mix LP\#8-16 Drop Height}

Increasing grout flow in Tanks 5-F and 6-F by increasing drop height is also a possibility. The underlying consideration is not to incur segregation during placement. During filling of Tanks 18-F and 19-F, SRR demonstrated that the bulk grout formulation with a slumpflow of 24 to 28 inches did not segregate when the drop height was 10 feet. $^{6}$ At this time no data are available to assure that the tank closure bulk fill grout with 28 to 30 inch slump-flows will not segregate when dropped 10 feet. Consequently, testing should be performed prior to increasing the drop height of mixes with up to 30 inches of slumpflow. Alternatively, observations should be made during initial filling operations to determine whether segregation occurs for 10 foot drop heights. As long as no segregation occurs, grout quality should not be affected by a change in drop height. Any segregation will negatively impact grout quality. 
SRNL-STI-2012-00578

Revision 0

\subsection{Grout Pumping and Delivery Rate}

The risk of uneven grout distribution within the tank is increased for Tanks 5-F and 6-F due to the presence of internal obstructions such as the cooling coils. Consequently actions which will enhance grout flow in the tank, but not impact the quality of the grout, should be considered for implementation. Delivery rate of grout into Tanks 5-F and 6-F should be increased to the extent possible. A higher capacity concrete/grout pump and faster production/delivery rate along with continuous placement at a higher rate will result in better grout spread/flow inside the tanks.

\subsection{Grout Quality}

Slump-flow, unit weight, and other fresh properties were used for quality control indicators to accept or reject grout deliveries for closing Tanks 18-F and 19-F. Compressive strength was also measured at 28 days to confirm that the bulk fill grout met the cured material requirement of 2000 psi. Compressive strength is not a modeled property in the FTF Performance Assessment (PA). The modeled parameters of interest to the PA include: saturated hydraulic conductivity, effective transmissive porosity, bulk density, particle density, and distribution coefficients for contaminants of concern $\left(\mathrm{K}_{\mathrm{d}} \mathrm{S}\right)$. 
SRNL-STI-2012-00578

Revision 0

Table 2-1. Quality Control Data for Fill Material from Tanks 18-F and 19-F

\begin{tabular}{|c|c|c|c|}
\hline Batch Ticket No. & $\begin{array}{l}\text { Spread/Flow } \\
\text { (in) }\end{array}$ & $\begin{array}{c}\text { Average } 28 \text { Day } \\
\text { Compressive Strength } \\
\text { (psi) }\end{array}$ & $\begin{array}{c}\text { Water to Cementitious } \\
\text { Material Ratio } \\
\text { (lb/lb) }\end{array}$ \\
\hline 032919 & 26.5 & 2800 & 0.572 \\
\hline 032941 & 27.0 & 2887 & 0.567 \\
\hline 032947 & 28.0 & 2853 & 0.571 \\
\hline 032968 & 24.0 & 2937 & 0.571 \\
\hline 032985 & 26.0 & 2840 & 0.567 \\
\hline 033007 & 26.5 & 2743 & 0.568 \\
\hline 033047 & 26.0 & 3220 & 0.569 \\
\hline 033077 & 25.0 & 3200 & 0.562 \\
\hline 033101 & 26.0 & 3043 & 0.567 \\
\hline 033127 & 25.0 & 2827 & 0.578 \\
\hline 033145 & 25.5 & 2603 & 0.568 \\
\hline 033169 & 26.5 & 2620 & 0.568 \\
\hline 033217 & 27.5 & 2763 & 0.565 \\
\hline 033511 & 24.5 & 2577 & 0.579 \\
\hline 033636 & 27.0 & 2957 & 0.567 \\
\hline 033662 & 26.0 & 2787 & 0.569 \\
\hline 033695 & 26.0 & 3027 & 0.565 \\
\hline 033726 & 27.0 & 2950 & 0.579 \\
\hline 033778 & 26.0 & 2720 & 0.580 \\
\hline 033798 & 26.5 & 2443 & 0.568 \\
\hline 033867 & 26.0 & 2253 & 0.581 \\
\hline 033897 & 26.0 & 2317 & 0.564 \\
\hline 034081 & 24.5 & 2447 & 0.577 \\
\hline 034097 & 27.0 & 2770 & 0.565 \\
\hline 034127 & 26.0 & 2883 & 0.568 \\
\hline 034139 & 26.5 & 2800 & 0.569 \\
\hline 034158 & 25.0 & 2343 & 0.578 \\
\hline 034173 & 27.0 & 2617 & 0.567 \\
\hline 034196 & 25.5 & 2967 & 0.563 \\
\hline 034911 & 27.0 & 2920 & 0.565 \\
\hline 034939 & 26.0 & 2680 & 0.566 \\
\hline 034954 & 25.0 & 2770 & 0.567 \\
\hline 034985 & 25.5 & 2577 & 0.573 \\
\hline
\end{tabular}


SRNL-STI-2012-00578

Revision 0

Table 2-1. Quality Control Data for Fill Material from Tanks 18-F and 19-F (continued)

\begin{tabular}{|c|c|c|c|}
\hline Batch Ticket No. & $\begin{array}{l}\text { Spread/Flow } \\
\text { (in) }\end{array}$ & $\begin{array}{c}\text { Average } 28 \text { Day } \\
\text { Compressive Strength } \\
\text { (psi) }\end{array}$ & $\begin{array}{c}\text { Water to Cementitious } \\
\text { Material Ratio } \\
\text { (lb/lb) }\end{array}$ \\
\hline 034998 & 26.5 & 3007 & 0.561 \\
\hline 033359 & 26.0 & 2550 & 0.580 \\
\hline 033375 & 28.0 & 2617 & 0.560 \\
\hline 033413 & 27.5 & 2413 & 0.563 \\
\hline 033430 & 27.0 & 2317 & 0.562 \\
\hline 033464 & 27.0 & 2693 & 0.560 \\
\hline 033478 & 26.0 & 2693 & 0.565 \\
\hline 37720477 & 26.0 & 2983 & 0.566 \\
\hline 37720490 & 26.0 & 2657 & 0.569 \\
\hline 37720520 & 25.5 & 1867 & 0.570 \\
\hline 37720538 & 25.5 & 3177 & 0.580 \\
\hline 37720567 & 27.5 & 2973 & 0.566 \\
\hline 37720584 & 26.5 & 2783 & 0.567 \\
\hline 37720606 & 27.5 & 2593 & 0.564 \\
\hline 37720620 & 27.0 & 2557 & 0.561 \\
\hline 37720652 & 25.5 & 2850 & 0.576 \\
\hline 37720669 & 28.0 & 2477 & 0.563 \\
\hline 37720700 & 24.0 & 3007 & 0.581 \\
\hline 37720715 & 28.0 & 2117 & 0.565 \\
\hline 37720737 & 25.5 & 2787 & 0.569 \\
\hline 37720753 & 27.0 & 3090 & 0.561 \\
\hline 37720785 & 25.5 & 3013 & 0.575 \\
\hline 37720798 & 27.5 & 2847 & 0.564 \\
\hline 37720830 & 27.0 & 2593 & 0.561 \\
\hline 37720845 & 26.0 & 2837 & 0.577 \\
\hline 37720866 & 25.0 & 2753 & 0.561 \\
\hline 37720881 & 26.5 & 3050 & 0.582 \\
\hline 37720908 & 26.5 & 3247 & 0.559 \\
\hline 37720924 & 27.5 & 3187 & 0.560 \\
\hline 37720951 & 25.5 & 3290 & 0.561 \\
\hline 37720969 & 28.0 & 2953 & 0.563 \\
\hline 37721007 & 27.5 & 2623 & 0.558 \\
\hline 37721029 & 26.0 & 2903 & 0.561 \\
\hline
\end{tabular}


SRNL-STI-2012-00578

Revision 0

Table 2-1. Quality Control Data for Fill Material from Tanks 18-F and 19-F (continued)

\begin{tabular}{|c|c|c|c|}
\hline Batch Ticket No. & $\begin{array}{l}\text { Spread/Flow } \\
\text { (in) }\end{array}$ & $\begin{array}{c}\text { Average 28 Day } \\
\text { Compressive Strength } \\
\text { (psi) }\end{array}$ & $\begin{array}{c}\text { Water to Cementitious } \\
\text { Material Ratio } \\
\text { (lb/lb) }\end{array}$ \\
\hline 37721060 & 25.0 & 3000 & 0.582 \\
\hline 37721077 & 28.0 & 2863 & 0.562 \\
\hline 37721086 & 26.5 & 3010 & 0.566 \\
\hline 37721101 & 27.5 & 3227 & 0.564 \\
\hline 37721139 & 28.0 & 2960 & 0.562 \\
\hline 37721158 & 25.5 & 3250 & 0.562 \\
\hline 37721172 & 25.0 & 3330 & 0.563 \\
\hline 37721187 & 28.0 & 3047 & 0.564 \\
\hline 37721223 & 27.5 & 2803 & 0.562 \\
\hline 37721259 & 28.0 & 2507 & 0.562 \\
\hline 37721265 & 25.5 & 3000 & 0.562 \\
\hline 37721289 & 27.5 & 3190 & 0.560 \\
\hline 37721373 & 26.0 & 2857 & 0.579 \\
\hline 035164 & 27.5 & 3263 & 0.562 \\
\hline 035189 & 26.0 & 3480 & 0.562 \\
\hline 035212 & 28.0 & 2947 & 0.561 \\
\hline 035256 & 26.5 & 3160 & 0.560 \\
\hline 035285 & 28.0 & 2303 & 0.565 \\
\hline 035321 & 26.5 & 3110 & 0.558 \\
\hline 035338 & 27.0 & 3207 & 0.561 \\
\hline 035376 & 27.0 & 2900 & 0.580 \\
\hline 035393 & 25.5 & 3560 & 0.561 \\
\hline 035424 & 28.0 & 3043 & 0.561 \\
\hline 035442 & 28.5 & 2870 & 0.562 \\
\hline 035463 & 28.0 & 2770 & 0.560 \\
\hline 035481 & 26.5 & 3497 & 0.562 \\
\hline 035509 & 27.0 & 3127 & 0.562 \\
\hline 035522 & 26.5 & 3730 & 0.560 \\
\hline 035553 & 27.0 & 3320 & 0.565 \\
\hline 035567 & 28.0 & 3303 & 0.563 \\
\hline 035590 & 26.5 & 3110 & 0.563 \\
\hline 035618 & 27.0 & 2933 & 0.562 \\
\hline 035667 & 27.0 & 3387 & 0.561 \\
\hline
\end{tabular}


SRNL-STI-2012-00578

Revision 0

Table 2-1. Quality Control Data for Fill Material from Tanks 18-F and 19-F (continued)

\begin{tabular}{||l|c|c|c||}
\hline Batch Ticket No. & $\begin{array}{c}\text { Spread/Flow } \\
\text { (in) }\end{array}$ & $\begin{array}{c}\text { Average 28 Day } \\
\text { Compressive Strength } \\
\text { (psi) }\end{array}$ & $\begin{array}{c}\text { Water to Cementitious } \\
\text { Material Ratio } \\
\text { (lb/lb) }\end{array}$ \\
\hline 035685 & 26.0 & 3337 & 0.561 \\
\hline 037105 & 25.5 & 3233 & 0.560 \\
\hline 037121 & 27.0 & 2883 & 0.561 \\
\hline 037151 & 26.5 & 2867 & 0.563 \\
\hline 037245 & 26.0 & 3267 & 0.579 \\
\hline 037259 & 28.0 & 2940 & 0.564 \\
\hline 037276 & 24.0 & 2940 & 0.562 \\
\hline 037290 & 26.0 & 3413 & 0.564 \\
\hline 037340 & 26.0 & 3347 & 0.564 \\
\hline 037355 & 27.5 & 2873 & 0.561 \\
\hline 037379 & 26.0 & 3117 & 0.561 \\
\hline 037396 & 27.5 & 2800 & 0.561 \\
\hline 037415 & 26.0 & 2217 & 0.582 \\
\hline 037419 & 24.5 & 3093 & 0.577 \\
\hline 037478 & 26.5 & 2017 & 0.578 \\
\hline 037489 & 26.5 & 2900 & 0.569 \\
\hline
\end{tabular}


SRNL-STI-2012-00578

Revision 0

\subsection{Conclusions}

Based on a review of the grout property data for Mix LP\#8-16 collected from Tank 18-F and 19-F quality control samples, the upper limit for slump-flow measured per ASTM C 1611 can be increased from 28 to 30 inches without affecting grout quality. However, testing should be performed prior to increasing the drop height from 5 to 10 feet or observations should be made during initial filling operations to determine whether segregation occurs as a function of drop heights between 5 and 10 feet. Segregation will negatively impact grout quality.

Additionally, increasing the delivery rate of grout into Tanks 5-F and 6-F by using a higher capacity concrete/grout pump will result in better grout spread/flow inside the tanks. 
SRNL-STI-2012-00578

Revision 0

\subsection{References}

1. C-SPP-F-00055, Rev. 2, "Furnishing and Delivery of Tank Closure Grout”, August 25, 2011, Savannah River Remediation, LLC, Savannah River Site, Aiken, SC, 29808.

2. Stefanko, D. B. and C. A. Langton, 2011. "Tanks 18 and 19-F Grout Fill Engineering and Performance Requirements”, SRNL-RP-2011-00977, Revision 0, August 2011, Savannah River National Laboratory, Savannah River Site, Aiken, SC, 29808.

3. Stefanko, D. B. and C. A. Langton, 2011. “Tanks 18 and 19-F Structural Flowable Grout Fill Material Evaluation and Recommendations”, SRNL-STI-2011-00551, Revision 0, September 2011, Savannah River National Laboratory, Savannah River Site, Aiken, SC, 29808.

4. Stefanko, D. B. and C. A. Langton, 2011. "Tanks 18-F and 19-F Tank Fill Grout Scale Up Test Summary”, SRNL-STI-2011-00749 Revision 0, December 2011, Savannah River National Laboratory, Savannah River Site, Aiken, SC, 29808.

5. Carroll, P. E., 2012. "Bulk Fill Grout Increased Fall Height and Slump”, HLE-TTR2012-006, Revision 0, September 18, 2012, Savannah River Remediation, LLC, Savannah River Site, Aiken, SC, 29808.

6. Carroll, P. E., 2012. E-Mail of Document Review Comments to M. S. Hay, C. A. Langton and D. B. Stefanko, September 26, 2012, Savannah River Remediation, LLC, Savannah River Site, Aiken, SC, 29808. 
SRNL-STI-2012-00578

Revision 0

\section{Distribution}

CC:

$\begin{array}{ll}\text { P. E. Carroll } & 704-71 F \\ \text { V. A. Chander } & 704-70 F \\ \text { R. W. Forty } & 742-5 G \\ \text { K. M. Fox } & 999-W \\ \text { M. E. Harrell } & 241-108-F \\ \text { J. E. Herbert } & 241-108-F \\ \text { S. D. Fink } & 773-A \\ \text { B. J. Giddings } & 786-5 A \\ \text { G. C. Arthur } & 241-109 F \\ \text { M. Hubbard } & 241-162 \mathrm{H}\end{array}$

S. L. Marra

B. A. Martin

M. E. Pallon

G. W. Patton

J. W. Rush

A. J. Tisler

R. O. Voegtlen

C. C. Herman

C. L. Atseff

G. D. Thaxton

Records (EDWS)
773-A

705-1C

717-11F

717-11F

241-108F

$704-26 \mathrm{~F}$

704-71F

999-W

241-162H

241-109F 